Vol. 17, $n^{\circ} 2 \mid 2013$

Varia

\title{
Making sense of violence? Reflections on the history of interpersonal violence in Europe
}

Richard Mc Mahon, Joachim Eibach and Randolph Roth

\section{(2) OpenEdition}

\section{Journals}

\section{Electronic version}

URL: http://journals.openedition.org/chs/1423

DOI: $10.4000 /$ chs. 1423

ISSN: 1663-4837

\section{Publisher}

Librairie Droz

\section{Printed version}

Date of publication: 1 December 2013

Number of pages: 5-26

ISBN: 978-2-600-01776-3

ISSN: $1422-0857$

\section{Electronic reference}

Richard Mc Mahon, Joachim Eibach and Randolph Roth, « Making sense of violence ? Reflections on the history of interpersonal violence in Europe », Crime, Histoire \& Sociétés / Crime, History \& Societies [Online], Vol. 17, n² | 2013, Online since 01 December 2016, connection on 19 April 2019. URL : http:// journals.openedition.org/chs/1423 ; DOI : 10.4000/chs.1423 


\title{
Making sense of violence? Reflections on the history of interpersonal violence in Europe
}

\author{
Richard Mc Mahon, Joachim Eibach and Randolph Roth ${ }^{1}$
}

$\mathrm{O}$ ver the last thirty years, historians of crime and criminal justice have taken a keen interest in the extent and nature of interpersonal violence in medieval, early modern and modern Europe. Drawing inspiration from Ted Robert Gurr's ground-breaking study of long-term homicide rates from the late middle ages to the latter half of the twentieth century ${ }^{2}$, historians have sought to map and explain longterm patterns in lethal interpersonal violence and, in particular, the reasons behind the seeming decline in homicide rates in many areas of Europe over time.

For some, the apparent decline in homicide rates reflects considerable and perhaps even fundamental change in cultural attitudes towards violent activity. Many have understood change in the context of a wider civilising process. Indeed, Norbert Elias's civilising process thesis has been the most prominent and controversial interpretative framework for explaining the apparent changes in patterns of homicidal violence. Pieter Spierenburg, drawing on Elias, argues, for instance, that patterns of violence have been profoundly altered not only by greater state intervention and broad changes in European socio-economic life but also by increased levels of 'affect control' which trickled down from the social elite to the masses over several centuries. In this view, as the state became more active in prosecuting violence through the courts, as interdependence among individuals increased with the development of new economic relationships, and as new ideas concerning appropriate behaviour spread from the elite, individuals became less likely to resort to violence to resolve conflicts. ${ }^{3}$ Steven Pinker, using a dazzling array of statistical evidence and a broad range of case studies, also draws on the concept of a civilising process to argue that the apparent decline in violence is a chief benefit and consequence of the impact of modernity on the western world. He credits especially the influence of Enlightenment thought since the eighteenth century. For Pinker, the "erosion of family, tribe, tradition, and religion" by the "forces of

The idea for this collection of essays was hatched in a cabin room of the Queen Mary at the SSHA conference in Long Beach, California in 2009. It was further developed at the conference 'Making Sense of Violence? Interdisciplinary Approaches to Violence: Past and Present' that we organized in Bern, Switzerland, in September 2011. We benefited greatly from the perspectives and ideas offered by all those who contributed to that conference. We are also particularly grateful to the Gerda Henkel Foundation, the Swiss National Science Foundation, the Swiss Academy of Humanities and Social Sciences, the Johanna Dürmüller-Bol Foundation and the MVUB of the University of Bern for their kind sponsorship of the conference.

2 Gurr (1982). Gurr's article sparked off considerable debate within the English historiography. See, for instance, Stone (1983); Sharpe (1985).

3 See Elias (1939) revised ed. (2000); Spierenburg (1994, 1996, 1998).

Crime, Histoire \& Sociétés / Crime, History \& Societies 2013, vol. 17, n², pp. 5-26 
individualism, cosmopolitanism, reason, and science" contributed to the decline in rates of interpersonal violence in western societies. ${ }^{4}$

Others have been somewhat more moderate in their claims. A number of historians, particularly those working on early modern Britain and Germany, have understood the alterations in patterns of violent activity as a consequence of changes in perceptions of male honour and the rise of individualism. They argue that, as community influence waned in the early modern period and new norms surrounding individual behaviour emerged, violence, over the course of the eighteenth century in particular, became less central to individual male identity and came increasingly to be the preserve of often marginalised sections of the lower orders. ${ }^{5}$ Some have also been highly critical of the civilizing process thesis and, in particular, have queried the reliability of the medieval homicide figures - preferring instead to base their analysis on the more reliable data from the early modern period. ${ }^{6}$ Greater state intervention and a wider process of social disciplining, often driven by church bodies, new work practices, and the expansion in the number of schools have also been credited with contributing to a diminution in violent activity among individuals. ${ }^{7}$

Others have adopted an even more sceptical approach to the evidence and have been suspicious of applying over-arching theories of socio-cultural change to explain the decline in homicide rates - preferring instead to emphasize changes in medical expertise and practice, in the age structure of the population and also the difficulties inherent in the use of the available sources. ${ }^{8}$ Outside of a directly European context (but with clear implications for it) Randolph Roth has also proposed an alternative framework for understanding variations in homicide rates over time which emphasizes the importance of trust in state institutions and, more broadly, the process of nation building in establishing low levels of interpersonal violence. ${ }^{9}$ In doing so, Roth is wary of any tendency to draw a "sharp line between pre-modern and modern states and personalities". ${ }^{10}$

The essays in this special edition trace the ebb and flow of violence within specific contexts without succumbing to the temptations of either a too narrow view or too broad a brushstroke. In doing so, they are generally critical of those who view changes in patterns of violent activity in Europe in the light of a wider civilising process and offer different approaches to the analysis of continuity and change in

4 For Pinker, the rise of the state, the development of webs of commerce, feminization, cosmopolitanism and an increasing resort to reason as a means of resolving conflict, have all contributed to the decline in interpersonal violence. Pinker (2011). Pinker and others, most notably John Carter Wood and Gregory Hanlon, have also looked to evolutionary psychology to provide a broad cross-cultural framework within which the history of interpersonal violence can be understood. Although we think this perspective is important and needs to be engaged with by historians of violence, unfortunately, reasons of space prevent us from discussing these issues here. See Pinker (2011); Carter Wood (2007, 2011); Hanlon (2013).

5 Shoemaker $(2001,2002)$; Eibach $(2003,2008)$.

6 See Schwerhoff $(1998,2004)$. For the debate between Spierenburg and Schwerhoff on the relative merits of their positions, see Spierenburg, (2001); Schwerhoff, (2002); Spierenburg (2002). For a good overview of the differing interpretations of the history of interpersonal violence in Europe, see Eisner $(2001,2003)$.

7 Eisner (2001).

8 See, for instance, Cockburn (1991); Carroll (2007).

9 Roth (2009). See also Spierenburg (2011a, 2011b); Roth (2011).

10 Roth (2009). 
the history of interpersonal violence. Gerd Schwerhoff offers a critical overview of changes in patterns of violence in early modern Europe - with a particular focus on how changes in violent behaviour in German-speaking countries reflected wider shifts in economic, social and cultural life. Through a study of the German historiography, he provides a thorough and compelling critique of those scholars who view changes in interpersonal violence in the light of a broader civilising process. John Cronin provides an excellent micro-study of elite violence in action by exploring the role of the duel in the banished Caroline Stuart court in the mid-seventeenth century. He too is sceptical about the applicability of Elias in understanding patterns of elite violence in the early modern period.

Manon van der Heijden explores patterns of violence among men and women in early modern Holland and, through the innovative use of legal records, draws attention to the prominence of women among the perpetrators of violence as well as the support in place for women within early modern neighbourhoods in Holland. In doing so, she skilfully raises key questions about the prevailing view of the relationship between women and violent activity and draws attention to considerable continuities in behaviour over time. In the final essay, Maurice Cottier and Silvio Raciti provide a penetrating analysis of the relationship between changes in patterns of violence and wider social and cultural change in Swiss cities and, in the process, provide a fresh and stimulating account of shifting practices in the use of interpersonal violence. In particular, they note a marked shift, in the late nineteenth and early twentieth centuries, away from the practice of sociable violence and the emergence of a new form of 'fatalistic' violence.

This introductory essay draws on the insights of these articles but also reflects, more broadly, on the history of interpersonal violence in Europe and, in doing so, engages with three key issues which emerge from and are central to the historiography: What is the extent of interpersonal violence in Europe since the late middle ages? What is the character and nature of such violence? Has interpersonal violence moved from the centre to the margins of European life? In addressing these three key questions, the introduction will also offer a critique of the dominant interpretations of the history of interpersonal violence in European life.

\section{THE EXTENT OF INTERPERSONAL VIOLENCE}

The dominant view within the historiography is that rates of interpersonal violence have decreased markedly in Europe over the last seven centuries. The evidence for this is (at least superficially) compelling. It is possible to point, for instance, to estimated rates of 110 homicides per 100,000 in fourteenth-century Oxford and Florence - rates which far exceed anything found in modern-day Europe. While these rates are exceptional even for the period, evidence from elsewhere in Europe suggests that rates were often in excess of anything found in the present with estimated rates of circa 20 to 40 homicides per 100,000 of the population found for a number of areas in the fourteenth and early fifteenth centuries. ${ }^{11}$ Following this highpoint, there appears to be a fall in homicide rates in the early modern period and certainly by the eighteenth century, when homicide rates fall below - often

Spierenburg (2008, pp. 15-16); Eisner (2001, p. 628). 
well below - 10 per 100,000 in many areas of Europe. By the nineteenth century, homicide rates in most areas of Europe were rarely in double figures and, according to Eisner, the European average for the nineteenth century was 2.6 per $100,000 .{ }^{12}$ Homicide rates reached an all-time low by the mid-twentieth century. Indeed, in some countries, there was a risk that homicide would disappear altogether from the national landscape. The rate in the Republic of Ireland in the 1950s was 0.23 per $100,000^{13}$ - amongst the lowest national homicide rates in recorded human history. Since the 1960s, there has been an increase in rates in many parts of Europe, but it has not come anywhere near the levels recorded for the late medieval period.

This apparent shift in the extent of interpersonal violence has been central to the civilising process thesis advocated by Spierenburg and others who have argued that changes in homicide rates reflect a wider transformation in the economic, social and cultural life of Europe. There are, however, serious problems with this analysis. To begin, the high homicide rates for medieval Europe probably exaggerate the extent of lethal violence relative to later periods. There is a very real possibility, for instance, that the medieval samples include homicide cases that occurred outside the cities but which were dealt with by the authorities in the cities. This would mean that there is a definite imbalance between the estimated homicide figures and the estimated population figures. ${ }^{14}$ The lack of reliable population figures is also a serious problem for anyone attempting to calculate accurate homicide rates with evidence that, in some cases at least, urban population figures have been significantly underestimated. ${ }^{15}$

Historians of homicide are also not always comparing like with like when they compare homicide rates from the middle ages with those of later periods. In an English context, as Roth has highlighted, the homicide rates from the early modern period are often derived from the number of indictments for homicide while those for the middle ages are generated from coroners' rolls. Indictments depend on the ability of the authorities to bring cases before the courts and are therefore less complete as sources for homicides than the more comprehensive coroners' inquests which capture cases at an earlier stage of the criminal process. This would suggest that any simple narrative of decline is problematic. The available evidence rather indicates that rates fluctuated considerably between the late middle ages and the early modern period with marked increases in the second half of the fourteenth and the late sixteenth centuries. ${ }^{16}$ There is then no obvious or consistent pattern of decline. There is also a difficulty for those who support the civilising process thesis in drawing on evidence from the fourteenth century without offering due attention to rates from the thirteenth century which indicate that rates at that time were actually lower than a century later. ${ }^{17}$ The use of the fourteenth century as a point of comparison can then serve to distort the difference between the middle ages and the early modern period.

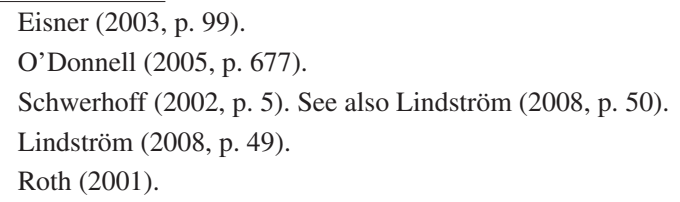

Sharpe, while questioning the validity of many of the homicide rates derived from medieval and early modern sources, points out that rates in Oxford in the 1340s were twenty-seven times those in Bristol in the previous century. He attributes this to differences in the source material rather than any shift in practice. See Sharpe (1985, p. 209). 
The evidence of a decline between the sixteenth and the eighteenth centuries is more compelling. There is, for instance, almost universal agreement that a substantial decline in homicide rates occurred in many areas of Europe during the seventeenth and eighteenth centuries. ${ }^{18}$ We need, however, to be careful here also as the late sixteenth and early seventeenth century was a time of particularly high rates in many regions. This again distorts the difference between the eighteenth and earlier centuries. The difference in rates between the late sixteenth century and the eighteenth century in England is, for instance, much greater than the difference between the early sixteenth century and the eighteenth century. This again suggests any broad narrative of decline driven by a wider civilising process is at least open to question. ${ }^{19}$

Comparisons between earlier periods and the present day are also problematic. This is particularly so, if we consider the impact of improvements in medical care. Recent estimates suggest that circa 50 per cent of victims in the late nineteenth century would have survived if they had access to the benefits of modern medical care and emergency services. ${ }^{20}$ Improved nutrition and health must also be taken into account. It may simply be that healthier individuals in the present day are better able to survive violent assaults. It might also be interesting to assess the degree to which this applies when comparing different societies in, say, the nineteenth century. Might, for instance, individuals in societies that experienced major episodes of famine such as Ireland, Belgium and Finland be more likely to die following violent attacks than those in countries spared the ravages of widespread food shortages? Remarkably there has, as yet, been no attempt to establish a correlation between homicide rates and broader trends in mortality and health over time and space.

The impact of medical care and nutrition on homicide rates also has implications for the civilising process thesis. High homicide rates, Spierenburg argues, are usually due to the prevalence of male-on-male fighting and the declining proportion of such cases over time must, he argues, be due to changes in the 'affect control' of individuals. Such male on male fighting must, however, be far less likely to lead to homicide in the present day due to medical intervention and improved nutrition. There are three reasons for this (1) these cases are often, in Spierenburg's words, 'accidents'; thus there is a lack of intent to kill in the first instance; (2) the protagonists are less likely to have pre-planned the attack and are, therefore, less likely to bring weapons to the scene; and (3) they are more likely than, for instance, cases of domestic violence to involve protagonists of similar strength. It is likely, therefore, that improvements in medical care would have a particular impact on the extent of homicides arising from male-on-male fighting relative to other forms of homicide.

If we allow for improvements in medical care, the impact of emergency services and improved nutrition, and take account as well of the need to revise the population estimates, especially when cases from outside city boundaries are considered, we

18 Eisner (2001); Schwerhoff (2011, p. 119).

19 Roth (2001). This decline was also, as is generally acknowledged by scholars, subject to periodic reversals. In Frankfurt on Main, for instance, the homicide rate rose from 7.5 per 100,000 in the early years of the eighteenth century to 11 per 100,000 by the 1740 s and fell substantially to 2.8 per 100,000 in the early 1780 s. See Eibach (2003, p. 103). This mid-eighteenth century rise in lethal violence was by no means unique to Frankfurt on Main and has yet to be fully explored and explained by historians. 
could reasonably argue that medieval homicide rates need to be reduced significantly before they are compared to rates in the present day. If we were to simply allow for improvements in medical care and emergency services, present-day rates could be very similar to rates in the eighteenth century with little substantial change over time in many areas. In some cases the rates for the eighteenth century would be lower than those for the late twentieth and early twenty-first centuries. Rates for the fourteenth century would still be higher than the European average of between 1 and 2 per 100,000 today but even here we need to be careful. First, rates calculated for the thirteenth century would be much closer to those in the present - again raising questions about any fundamental decline in experiences of interpersonal violence. Second, and perhaps most crucially, questions can also be asked about the use of homicide rates as an indicator of the extent of non-lethal interpersonal violence. Central to the civilising process thesis is the claim that homicide rates can be seen as indicators of the wider prevalence of violence in a society. Spierenburg, in fact, argues that there is a clear relationship between lethal and non-lethal violence. He even develops a means to calculate the connection. He argues that if we want to 'prove' that there is a "doubling of men's aggressive impulses over a certain period", we would need to quadruple the homicide rate to support our claims. ${ }^{21}$ This kind of calculation, although ostensibly reasonable, is based more on assumptions rather than on evidence of the relationship between lethal and non-lethal violence.

We need to at least entertain the idea that it is possible for there to be a difference in homicide rates between different societies and/or periods without this necessarily reflecting a fundamental difference in the extent of non-lethal violence. To take but one example, the rate of spousal homicide in Ireland in the 1990s was close to four times the rate in the 1960s. ${ }^{22}$ If we applied Spierenburg's model to our figures for Irish spousal homicide, it would mean that between the 1960s and the 1990s men and women in Ireland were nearly twice as likely to resort to violence towards their partners over the space of thirty years (through either an increasing number of people resorting to violence or some resorting to domestic violence on a more regular basis). While this is possible, it is open to question. Given the increased awareness of the problem of domestic violence in Ireland in recent decades and the greater supports in place for women (and, to a lesser extent, men) to combat or at least evade domestic abuse, it would be surprising if this coincided with an upsurge in the use of non-lethal violence against partners. A more likely explanation is that the increased rate of spousal homicide reflects a greater severity in the use of violence as men, in particular, feel their position is increasingly threatened within the home. In this case, the use of the rate of spousal homicide as a broad indicator of the extent of nonlethal spousal violence is flawed. It suggests rather that homicide rates offer a sense of the severity of violence and reveal the degree to which violence is contained and controlled rather than its extent. Nor, as will be argued below, should homicide rates be taken as a simple index of levels of 'affect control'.

Arguments for a fundamental change in the extent of interpersonal violence over time are flawed. This is due to problems with the available sources, the need to recognise the impact of improvements in medical care and nutrition, and doubts over

\footnotetext{
21 Spierenburg (2001, p. 92).

22 Rates for the 1960s were estimated using the annual published reports of An Garda Síochána. The rates from the 1990s were derived from Dooley (2001).
} 
the degree to which rates of homicide might reflect the extent of non-lethal violence. Thus, while there are changes over time, these cannot be accounted for by a wider civilising process or any fundamental transformation in the extent of 'affect control' among the general population. This conclusion is further reinforced if we look to the character of violence in Europe since the late medieval period.

\section{THE CHARACTER OF VIOLENCE}

The dominant view within the historiography is that honour was central to life in early modern Europe and to the practice of violence. The general histories of violence by Spierenburg and Robert Muchembled emphasize the degree to which the character and practice of violence was bound up with and expressed through prevailing concepts of honour. Honour was a valuable commodity in need of protection: when under threat it could be defended by force. ${ }^{23}$ The essays in this collection confirm the centrality of honour in the practice of violence in early modern Europe. Schwerhoff, reflecting a broader view in the German historiography, argues that conceptions of personal honour, albeit in varied forms, were at the heart of most acts of violence in the early modern period. Cronin too notes the centrality of concepts of honour in elite culture and how violence might be used to uphold and defend status among elites in the seventeenth century. This is certainly evident in the operation of the exiled court of Charles II, and it is possible to find similar examples in other royal courts in early modern Europe ${ }^{24}$ Cottier and Raciti also note the prevalence of violence as a means of asserting position and place in eighteenth - and nineteenth-century Switzerland. Violence in these studies is primarily a male preserve, but as van der Heijden reminds us, women too could use violence to protect, assert and advance status when necessary. Indeed, the study of women as perpetrators of violence has too often been overshadowed by, and relegated to a position of secondary importance, by the oft-cited fact that men make up the vast majority of homicide perpetrators and victims. Efforts to look beyond lethal violence reveal, however, a more complex picture. As van der Heijden and other have demonstrated, at the lower levels of the criminal justice system women were often prominent among those accused of violent crime. Perhaps the most striking aspect of such research has been to highlight how little difference there often was between the character of female violence and that of their male counterparts. ${ }^{25}$ While men might predominate in the perpetration of acts of lethal violence, women also participated, in similar ways, in the practice of violence.

There is also broad agreement among historians that the relationship between honour and the practice of violence has changed or at least evolved over time, although there has been considerably less agreement over the nature of that change. Spierenburg, for instance, believes that there has been a long-term shift in the character of violence - in particular a move from impulsive and ritual violence in

\footnotetext{
23 Spierenburg (2008); Muchembled (2012); Shoemaker (2001); Walz (1992). Some, however, argue that this perspective endows the arbitrariness of interpersonal violence with too much of a social logic. See Wettmann-Jungblut (2003, p. 57).

24 See, for instance, Kiernan (1988); Muchembled (2012).

25 van der Heijden (2013). See also Warner et al. (2008); Kilday (2007); Dinges (1991); Eibach (2007).
} 
the late medieval period to a greater emphasis on instrumental and planned violence in the modern era. He also links this change to a broader and gradual 'spiritualization of honour' in Europe over the course of the early modern period whereby honour increasingly depended on an individual's sense of self-worth. It was no longer bestowed upon the individual by the wider community. ${ }^{26}$

Others, while not denying that change occurred, have criticized key aspects of this position and, in particular, its portrayal of violence in medieval society as impulsive. A number of German historians, most notably Schwerhoff and Martin Dinges, have argued strongly that there was often much more to violent confrontations than a simple impulsive reaction to external threat. Schwerhoff, for instance, argues that there was a strong element of ritual surrounding incidents of violence in late medieval and early modern Europe which served to contain and control the extent of violent activity and which reflected the ability of men to control their emotions. This, he argues, is reflected in the fact there were often different stages in the escalation of conflicts which allowed the participants to decide whether or not to participate in or withdraw from a dispute or gave third parties the opportunity to intervene. ${ }^{27}$

There was also often more to such conflicts than simple impulsive reactions to provocative gestures and minor infringements. They could reflect long-standing and deep-rooted conflicts within communities. Schwerhoff argues that the line between questions of honour and material interests was often blurred. Many violent incidents were rooted in local conflicts between individuals and families. ${ }^{28}$ The long-standing conflicts which underlay many violent confrontations and the ritualised nature of many violent encounters suggest that there was more to medieval and early modern violence than an impulsive reaction to a momentary questioning of individual honour.

Spierenburg, however, rejects these criticisms and claims that "ritual and impulsive violence are wholly commensurable" and that pre-existing disputes are not incompatible with impulsive acts of violence. He is, indeed, highly critical of historians who have argued that the ritual elements in violent acts reveal a pronounced level of self-control. Spierenburg argues instead that there is no necessary inconsistency between the rituals which surround acts of violence in the middle ages and the categorization of such violence as impulsive or at least as more impulsive than in later periods. His argument is essentially that ritual practices are fixed and so deeply ingrained that there is relatively little need for calculation or planning: the ritual is carried out with limited reflection. Moreover, he argues that historians have consistently failed to demonstrate the existence of a link between ritual and self-control in the middle ages. ${ }^{29}$

This does not, however, seem to imply for Spierenburg that there is no connection between ritual and self-control, but rather that it simply does not apply to the same extent in the context of violence among ordinary people. He allows, for instance, for the possibility of a connection between ritual and self-control in his discussion of the elite duel. Here, the rituals surrounding the act reflect a propensity for self-control and an ability to contain and express violence within clearly defined limits. Thus, for

Spierenburg (2008, pp. 7-10).

27 Schwerhoff (2011, pp. 120-122); Walz (1992); Dinges (1994); Eriksson, Krug-Richter (2003).

28 See also Ruff (2008); Ludwig (2011); Mc Mahon (2013, chapter two).

29 Spierenburg (2008, p. 36, 2001, pp. 93-97). 
Spierenburg, the duel represents "a major innovation in violence" in that "the delay between the challenge and the actual fight promoted the restraint of emotions. It was a step away from outright impulsiveness in the direction of planned violence". ${ }^{30}$

This raises a rather obvious question: if a time gap can indicate a degree of self-control in elite duels, which were undoubtedly subject to ritual practices, why not in more popular forms of violence? Spierenburg, however, does not apply this reasoning to more popular forms of violence that also entailed a clear delay. For instance, in early modern Germany, the practice of Ausfordern aus dem Haus (Challenging out of the house or 'house scorning') required the challenger to visit his opponent's house and call him out to fight. In these cases, there could be a considerable time difference between the original dispute and the challenge. Days could pass, which suggests planning (biding one's time until the moment was right to confront one's opponent) or reflection (a struggle over whether to confront one's opponent). ${ }^{31}$ Spierenburg regards such delays as less indicative of individual selfcontrol than elite duels but provides no real evidence to support his position. Indeed, while Spierenburg criticises others for failing to establish a clear connection between ritual and self-control, he does not provide clear evidence that ritual did not involve a considerable level of self-control. Some of the evidence provided by Spierenburg, in fact, suggests a considerable degree of calculation rather than a ritualized response with a relative lack of forethought. To take but one example, revenge killings in the medieval period were often carried out on the anniversary of the original homicide, which suggests a marked level of planning and calculation involved in the act. ${ }^{32}$ Particularly when compared to the rather uncontrolled violence, detailed by Cronin, among some members of the seventeenth-century elite. ${ }^{33}$

It is also impossible to assess whether or not ritual recurrently failed to inhibit violence, given that incidents where ritual may have succeeded in so doing are often not recorded in the criminal records. ${ }^{34}$ The evidence that does exist suggests that the intervention of third parties was common and that many cases that appeared before the courts involved incidents where the confrontation stopped short of physical violence. In the southern German town of Constance between 1430 and 1460 no less than 309 (53 per cent) out of a total of 582 registered violent conflicts were merely threats with weapons, mostly so-called knife pulling ('Messerzücken') without any injuries. ${ }^{35}$ Higher homicide rates in the middle ages might reflect the greater failure rate of ritual to contain violence (this again would be a suspect claim), but given the doubts that now surround the apparent changes in homicide rates this is a dubious proposition.

Patterns of violence in the present day, moreover, appear to be characterised by the very impulsivity that the civilising process thesis associates with the middle ages. In England between 1992 and 2003, for instance, 45.6 per cent of known homicides

\footnotetext{
$30 \quad$ Spierenburg $(2008$, p. 73).

31 See Eibach (2008, pp. 59-61); Krug-Richter (2004); See also Spierenburg (2008, pp. 69-70).

32 Spierenburg (2008, p. 36).

33 Cronin (2013).

34 Spierenburg has argued that ritual 'recurrently' failed to contain violence in the late middle ages (Spierenburg 2001, p. 96).

35 Schuster (2000a, pp. 71 \& 95). See also Dean (2007, chapter nine).
} 
arose from "quarrel, revenge or loss of temper". ${ }^{36}$ The evidence from central Europe also indicates that there may have been a gradual loosening of the rituals surrounding violence in the eighteenth and nineteenth centuries which suggests that violence has probably become more, not less, impulsive. ${ }^{37}$ The notion of a shift towards more 'instrumental' violence in the modern era is also open to question. Indeed, the contextual data that Spierenburg provides on homicide in fourteenthcentury England indicates that, in certain locations, homicides arising from burglary or robbery could account for "no fewer than 25 and 30 per cent" of cases. ${ }^{38}$ Such high levels of "instrumental "violence", no matter how violent or unplanned, do little to support the argument that modern homicide patterns are characterised by a greater resort to violence for immediate personal gain - especially given that in England, between 1992 and 2003, homicides "in furtherance of theft or gain" or more 'instrumental' violence accounted for only 7.25 per cent of cases. ${ }^{39}$

It is also often difficult to establish clear differences between the means used in present-day violence and the violence of some earlier periods. Even with the greater availability of firearms in the present day, gun-related homicide in many areas of Europe remains rare. In modern England, only 9 per cent of homicides between 1992 and 2003 involved firearms while 16 per cent or nearly double involved hitting or kicking while the most common method of killing was with a sharp instrument accounting for just under a third of all cases. ${ }^{40}$ The prominence of the knife in modern English homicide cases is, in fact, similar to practices detected in early modern Amsterdam. ${ }^{41}$ Curiously, experiences in both modern England and early modern Amsterdam contrast with Italian cities in the late medieval period, where the use of knives as weapons by ordinary people was actually quite rare. ${ }^{42}$

There can be little doubt that evidence on patterns of violence in the present, coupled with questions over the quantitative data, raise serious problems for any thesis based on a study of interpersonal violence that posits a fundamental shift in the 'affect control' of ordinary people between the middle ages and the present. Indeed, it is also worth reflecting on the value of homicide as a means of establishing a viable comparative measure of the extent of 'affect control' within different population groups. Does a higher homicide rate necessarily imply a lower level of 'affect control'? For instance, does the fact that there are lower homicide rates in the thirteenth century than in the fourteenth century imply that fourteenth-century men were less able to control themselves than their thirteenth-century forefathers? Or to take a more modern example, does the fact that there were lower homicide rates in Finland in the nineteenth century than in the twentieth century necessarily imply that people who lived Finland in the latter century were less capable of controlling

Povey (2004, p. 16).

37 See Cottier, Raciti (2013); Eibach (2003, pp. 236-241). On the de-ritualization of violence as a result of constant warfare, see Lorenz (2007).

38 Spierenburg (2008, p. 39).

39 Povey (2004, p. 16).

$40 \quad$ Ibid. (p. 11).

41 Spierenburg (2001, pp. 81-96).

42 See Dean (2007, pp. 169-70). 
their emotions than their predecessors in the nineteenth century ${ }^{43}$ Perhaps it does, but it would be a large claim to make based on such limited evidence and would marginalise other factors which could offer more compelling reasons for such differences. It ultimately runs the risk of writing a history of control which fails to fully acknowledge a history of conflict.

There is also the danger of engaging in a circular argument, namely that we know there were low levels of 'affect control' because there were high rates of homicide and there was a high rate of homicide because there was a low level of 'affect control' - thus we risk using the known to quantify the unknowable. It might, of course, be argued that there is considerable corroborating evidence to support the idea that there was a lack of 'affect control'. This might be seen, for instance, in the original focus of the civilising process thesis on dining habits and bodily functions in the late middle ages which suggests that men and women inhabited a somewhat less controlled world. This, however, raises a curious anomaly when applied to the history of interpersonal violence, namely the position of women. Why did women not demonstrate a similar propensity for lethal interpersonal violence in the public sphere, despite being subject to a similar lack of 'affect control'?

The fact that they did not would again indicate that the practice of violence was controlled and limited. It was not primarily a product of lower levels of 'affect control'. In this sense, homicides rates reflect the complex interplay of conflict and control and cannot be used as a simple or straightforward index of either. Ultimately, the study of practices of violence reveals considerable similarities in the character of interpersonal violence across time and cultures, and serves to undermine any simple narrative of a fundamental change or transformation in the behaviour of men and women over time.

\section{MARGINALISATION}

If the evidence for a transformation in the extent and character of violence in Europe is weak, what then of the broader place and position of interpersonal violence in European life from the middle ages to the present day? For many historians, such a transformation is indisputable. Central to the civilising process thesis, in particular, is the view that there was a fundamental shift in the place of, and attitudes to, violence from the middle ages to the present, driven, in large measure, but not exclusively, by interrelated changes in attitudes among elite groups; the trickle down of elite attitudes to violence to other social groups; and by wider processes of urbanization and increasing state intervention.

From this perspective, interpersonal violence was central to European life in the middle ages and this was reflected in a widespread acquiescence in interpersonal violence among men of all social ranks. From the late fourteenth century to the mid-seventeenth century, there was, however, a gradual, if halting, process of criminalization which, developed in tandem with a wider process of urbanisation and the early stages of state formation. Initially, this process took account of older

43 Lindström notes that "from the eighteenth century on the aggregated homicide rate in Finland continued to increase up to the 1920 s, when it reached a level of more than 8 killings per 100,000". Lindström (2008, p. 45). 
or more 'popular' concepts of what constituted legitimate action (often through the judicious use of the pardon) but ultimately it led to the consistent prosecution of serious violent crime by the state. This process of criminalization was related to and reinforced by a series of developments such as the introduction of police forces and the emergence of formalised and structured sporting bodies which led to the increased marginalization of violence within European society in the nineteenth and twentieth centuries. Throughout this process, violence moved, it is argued, from the centre to the margins of the socio-cultural landscape of Europe, reflecting and reinforcing a greater desire to control violence and increased sensitivity towards it. ${ }^{44}$

There are again problems with this narrative of a shift in interpersonal violence from the centre to the margins of European life. While men from all social groups could engage in violence in the late middle ages, we need to be careful in ascribing a central or necessarily dominant position to interpersonal violence in everyday life in medieval and early modern Europe. This would be to downplay the considerable evidence that exists of the efforts made to contain and control violent activity.

There were certainly efforts made throughout the late medieval and early modern period to regulate and control violence. The elaborate reconciliation ceremonies of the middle ages do not, for instance, suggest that there was a lack of sensitivity towards violence or a lack of desire to control it - indeed, they seem to involve a clear recognition that a wrong had been perpetrated and that restitution was needed in order to prevent further action. ${ }^{45}$ In this sense, reconciliation reflects a clear desire to control and contain violence rather than simply acquiescence in the perpetration of violent activity. As Spierenburg has noted, private reconciliation was an "important tool of social control". ${ }^{46}$

Within many European cities, guilds could also take steps to ensure that their members did not step outside the bounds of acceptable behaviour. Guild statutes are full of demands to "avoid swearing and insults in pubs, not to bring weapons to festivities, to pull knives, to kick down doors or to fight". ${ }^{47}$ Violence, of course, could at times play a crucial role in the attempt to resolve conflicts and could be resorted to in ways that have few, if any, modern-day equivalents in European society. Certain forms of violent behaviour were tolerated and could be regarded as legitimate, but only if the participants followed accepted rules and kept violence within certain limits. This suggests that violence could also be used, as Schwerhoff and others have argued, in a relatively planned and calculated way as a means of negotiating conflict and keeping violence (not always successfully) within manageable limits. ${ }^{48}$ There is, in this sense, a difference between a society where the legitimate use of violence is more widely dispersed and resorted to by a variety of different actors and one in which violence is inevitable and the central means of dealing with conflict. Indeed,

\footnotetext{
$44 \quad$ Spierenburg (2008, chapters two and six).

45 Spierenburg (2008, chapter two).

46 Spierenburg (2008, p. 50).

47 Eibach $(2008$, p. 58). On the importance of guilds in controlling violence in medieval London, see Hanawalt (1993).

48 See Schwerhoff (2004). Hannah Skoda has also noted an ambivalence at the heart of medieval attitudes to violence which at the same time recognised the use of violence to impose order, but also its potential for disorder. She argues, plausibly, that "violence was not accepted as inevitable or its presence straightforwardly condoned”, Skoda (2013, p. 2). While violence could be common and widely practiced, it was not "so socially integral as to be deemed acceptable", Skoda (2013, p. 50).
} 
what is striking about violence in the late middle ages is the degree to which it was kept within certain bounds and limits and not allowed to play too disruptive a role in European life, long before the Enlightenment and the rise of the modern state. Violence might be allowed, but it was not allowed to disrupt the prevailing order.

Aside from the use of ritual to contain and control violence, the desire to limit violent conflict can be seen most obviously in the fact that the primary evidence for violent activity in the late middle ages and early modern period comes from sources that were dedicated to its control, namely courts records. This suggests that at the very least there were alternative strategies available when it came to dealing with conflict: violence and the law, while by no means mutually exclusive strategies, could compete as a means of dealing with conflict. Moreover, as the courts came increasingly to provide a viable forum for the resolution of disputes, ordinary people were more than willing to use them - indeed, the absence of overt or effective resistance to the prosecution of violent crime is a striking feature of the operation of the courts in many countries. The prosecution of violent activity through the court system, in fact, depended to a considerable degree on the participation of ordinary people. ${ }^{49}$

The courts could be used to prosecute violence both in the public and private spheres.$^{50}$ In some areas, it is clear that courts, along with communal interventions, were crucial in controlling problems such as domestic violence. As van der Heijden clearly demonstrates, neighbours helped to ensure that domestic violence did not disrupt urban life in early modern Holland. ${ }^{51}$ Indeed, the assumption that women in the early modern period were more vulnerable to, and more frequent victims of, domestic violence is at least open to question. As Julie Hardwick has argued, in the context of early modern France, women often had as much, or at times even greater, protection against the more extreme forms of violence than their modern-day counterparts. ${ }^{52}$ In Germany and Switzerland, women were also active in pursuing cases of domestic violence through the courts. ${ }^{53}$

The participation of ordinary men and women in the prosecution of violent crime also cannot be explained by the trickle down of elite attitudes and manners. It reveals over time a consistent desire on the part of ordinary people to prosecute various forms of violent activity and, in turn, to control rather than acquiesce in the perpetration of violent acts. ${ }^{54}$ Even where the courts failed to secure convictions, such failure should not necessarily be taken as evidence of a lack of concern but may

49 See Mc Mahon (2008). In a review of the cited book in this journal, Spierenburg states, rather bizarrely, that the introduction tries to 'revive' the concept, introduced by Lenman and Parker, of a judicial revolution. The introduction, in fact, provides a critique of the applicability of that concept to early modern Europe and notes that a number of essays in the collection "serve to undermine" Lenman and Parker's thesis. Spierenburg (2010).

Dinges (2004).

51 van der Heijden (2013).

52 In her discussion of domestic violence in early modern France, Hardwick argues that "although a seventeenth-century woman was legally subject to her husband's discipline, wives themselves as well as individuals and institutions in local communities publicly negotiated the parameters of that discipline. A twentieth-century woman living in a community that valorized romantic, companionate, and privatized ideals of marriage was, by contrast, isolated and wary of public acknowledgment of her status as a battered wife." Hardwick (2006, p. 1).

53 Schmidt (1998).

54 See Mc Mahon (2008). 
rather simply imply a different means of dealing with conflict. To draw a parallel with infanticide cases, the high acquittal rate for this offence in parts of eighteenth and nineteenth-century Britain does not necessarily mean that juries acquiesced in the killing of new-born babies or even that they thought such behaviour excusable or legitimate but rather may, as Richard Ireland has argued in the context of nineteenth-century Wales, suggest that they thought there were alternate means of dealing with offenders rather than imposing the full rigours of the law. ${ }^{55}$ Similarly, it may be that the importance of repairing social relations within communities through reconciliation and compensation took precedence in some respects over the full imposition of a criminal sanction which might aggravate rather than resolve a conflict. ${ }^{56}$ Indeed, such practices are, at least in the context of non-lethal violence, by no means unheard of in the present day.

The notion, central to the civilising process thesis, that urbanization and the greater intervention of the state are necessary pre-conditions for low or declining homicides rates is also open to question. Recent studies have revealed that rural areas in which the state did not take on an overt and interventionist role were not necessarily places where violence played a central part in social and cultural life. In the early modern Isle of Man, violence was not regarded as a serious problem and the incidence of violence appears quite low. Yet, the island lacked any substantial urban centre, it was economically underdeveloped and was largely cut off from the encroachment of the centralising state. Ordinary people on the island also had little by way of elite example to draw on. ${ }^{57}$ Julius Ruff has also demonstrated that in rural areas of eighteenth-century France, where the courts played a marginal role in the control of everyday violence and where the criminal justice system in general was relatively weak, homicide rates were as low as 0.72 per $100,000 .^{58}$ Dag Lindström, although he charts a long-term decline in homicide in Sweden, highlights the fact that homicide rates were often quite low in some of the more remote, rural and economically isolated areas of Northern Sweden in the sixteenth century and were, if anything, comparable to rates found in the present day. ${ }^{59}$ Peter King has also demonstrated that homicide rates were often higher in urban than rural areas of England and Wales in the nineteenth century and that any clear link between urbanization and declining homicide rates is highly problematic. ${ }^{60}$ Evidence from nineteenth-century Ireland also suggests that rural, economically under-developed regions often had relatively low rates of homicide. ${ }^{61}$ On the other hand, in the court records of late medieval towns we find relatively high homicide rates in spite of urbanisation, differentiation of social roles and the early stages of state formation. Such evidence calls into question any notion of a fundamental difference in

\footnotetext{
55 Ireland (1997).

56 In many cases of domestic abuse, for instance, the local or ecclesiastical courts served as mediators in marital conflict and were used primarily to remind violent or drunken husbands of their duties. For Catholic Bavaria, see Beck (1992); for Lutheran Frankfurt, see Eibach (2007).

57 Sharpe (2008, pp. 131-32).

58 Ruff, (2008, p. 37). This rate is based on prosecutions but even if the rate was five times higher it would not be wholly out of line with rates in the present day - particularly if we allow for the impact of improvements in medical care.

59 Lindström (2008, p. 54).

60 King (2010).

61 Mc Mahon (2013).
} 
the rate of lethal interpersonal violence in rural societies with relatively low levels of state intervention and those which have more elaborate state structures.

The argument here is that low homicide rates do not depend on urbanization, overt state intervention or consistent application of the criminal law, or more specifically the general criminalization of violence, but rather are rooted ultimately in the willingness and ability of communities, when faced with conflicts, to contain and control them both outside and inside the available criminal justice apparatus. This does not mean that the presence of a criminal justice system is insignificant (the evidence suggests non-state societies produce higher levels of interpersonal violence) but rather that a punitive, top down imposition of the criminal law is not a necessary precondition for low rates of homicide. Indeed, the available evidence, from throughout Europe, suggests that the control of violence was due to the fact that ordinary people were often enthusiastic participants in the courts and were willing, more generally, to participate in the control of violent activity through a variety of strategies for the negotiation of conflict. There is ultimately a clear continuity in the desire to control and contain interpersonal violence over time.

Of course, reactions to violence took different forms at different times and in different places and the ability to deal with violent conflict depended always on the resources available and the related priorities of those involved. In this sense, the history of violence in modern Europe might be best understood less as involving a move in violent activity from the centre to the periphery of social and cultural life but may more profitably be understood as reflecting 'shifting degrees of marginality' in violent action which, depending on circumstances, might see violence move either closer to or further away from the centre of everyday life. It should be the task of the historian to map how and why these changes occur across time and space without imposing fixed distinctions between 'civilized' and 'less civilized' societies or between the 'pre-modern' and the 'modern' ${ }^{62}$

There is, of course, one area where change is most obvious and profound, namely the profile of the participants in violent activity. The evidence from the late medieval period indicates that men from all social ranks participated in violent activity (albeit with limited interaction across social boundaries). ${ }^{63}$ Urban elites in central Europe, for instance, were regularly accused of violent crime and the exercise of political power was by no means inconsistent with the resort to acts of often serious interpersonal violence ${ }^{64}$ Indeed, members of the urban elite were, if anything, overrepresented among the perpetrators of violence in the surviving sources for late medieval central Europe. There was also little that was distinctive about elite violence as it tended to follow established rituals of violence prevalent in the wider culture. ${ }^{65}$

This situation was to change gradually over the course of the early modern period. Elites increasingly withdrew from participation in a shared form of violence and when they did engage in violent activity it was, by the nineteenth century, largely

62 For a framework for tracing the causes of fluctuations in homicide rates over time, see Roth (2009). See also Mc Mahon (2013).

63 Dean notes that "violence [in late medieval Italy] rarely ascended or descended the social scale". Violence across 'status boundaries' tended to follow particular and often predictable patterns: "the violence of husband against wife, of men against prostitutes, of men or women against local officials or agents (...)” Dean (2007, p. 171).

64 For Zurich, see Burghartz (1990) and for Constance, see Schuster (2000b).

65 Schwerhoff (2013). 
restricted to the exclusive and distinctive practice of duelling. The duel was, as Schwerhoff argues, increasingly a means of imposing social distinctions - it allowed for the negotiation of conflicts and the assertion of status within the elite while also allowing them to distance themselves from the violent practices of the masses (even if the elite duel, as Cronin clearly demonstrates, could often descend to the level of a fairly brutal contest). ${ }^{66}$

Members of the emerging middle classes in the cities of central Europe also began to distance themselves from the general practices of violence in the eighteenth century. There was, for instance, a marked change in the social composition of offenders before the urban courts of central Europe over the course of the early modern period ${ }^{67}$ Cottier and Raciti also note that Swiss cities saw a marked change in the practices of violence in the nineteenth and twentieth centuries. They point to the gradual withdrawal of middle class participants in violence, the loosening of rituals of honour and the development of new and distinctive forms of violence. ${ }^{68}$

From the eighteenth century onwards, ritualised violence seemed to lose its force as a common or shared means of communication. Its ability to act as a shared language weakened as social and cultural divisions became increasingly marked over the course of the early modern period. The middle classes, in particular, became reluctant to be involved in the game of violence - preferring the new and more refined sociability of the coffee house to the rough rituals of the tavern. ${ }^{69}$ This change was, moreover, not simply a central European phenomenon. In Ireland too there is a sense that the emerging middle classes increasingly distanced themselves from the violent practices associated with the duel in the early nineteenth century and the more rambunctious practices of the eighteenth century. ${ }^{70}$ In eighteenth-century England, there is evidence of a rejection of older conceptions of male honour among the middle classes and a greater reluctance to engage in violent activity. ${ }^{71}$ This rejection of violence by an emerging middle class persists to the present day. Perpetrators of lethal violence are today drawn predominantly from the ranks of the unemployed and marginalised. ${ }^{72}$

Yet we need again to be careful not to read these developments as simply a narrative of change with violence moving from the centre to the margins of European life. In Italy, the birth place of the duel, the centrality of interpersonal violence in late medieval elite culture can, for instance, be questioned. Trevor Dean highlights how most duels in late medieval Italy either failed to take place or came to a speedy conclusion after "one or two bloody blows". A death arising from a duel was rare and tended to occur "only by accident". ${ }^{73}$ Studies of Renaissance Italy also suggest that, amongst the elite at least, violence was often a last resort rather than a common or central practice and that 'verbal duelling' was often a legitimate and respected means

\footnotetext{
Schwerhoff (2013); Cronin (2013).

${ }^{67}$ Eibach (2009, pp. 201-204).

68 Cottier, Raciti (2013).

69 Eibach (2003, pp. 241-252).

70 Kelly (1995).

71 Shoemaker (2001).

72 Brookman (2005, p. 39).

73 Dean (2007, p. 180).
} 
of dealing with conflict. ${ }^{74}$ There was an upsurge in the practice of duelling in Italy in the early sixteenth century, but this was followed by a rapid decline in the latter half of the century. Indeed, a survey of the history of the duel generally reveals the failure of violence to take on a central role in the negotiation of conflict amongst the European elite. Italy, Germany, the Dutch Republic, Spain, Scandinavia and Switzerland were, at best, lukewarm adherents to the practice of duelling in the sixteenth and seventeenth centuries and in some areas the duel did not take hold at all. France did embrace the duel in the seventeenth century but it was, in the words of one historian, an "exception" and the nature of violence among the French elite is wholly outside the general patterns of violence found over the long term in European life. ${ }^{75}$ Even here, efforts were made to ensure that the duel did not pose too great a threat or became too central to life at court. The duel might be tolerated or even indulged at certain courts but it is less clear that it was central to the lives of the elite throughout Europe. Moreover, its practice and meaning changed considerably over the centuries. ${ }^{76}$

We need to be careful also not to see the eighteenth century as a moment when the elite and middle classes abandoned the use and practice of violence. The duel re-emerged in Germany, for instance, in the late nineteenth century with circa 8,000 students duels reported annually in the 1890s, while in France there were, on average, 300 duels reported every year in the last quarter of the nineteenth century. ${ }^{77}$ Moreover, as Cottier and Raciti skilfully demonstrate, although the middle classes largely withdrew from forms of sociable violence or honour contests, violence often re-emerged in new forms of intimate and fatal violence in the respectable cities of central Europe in the early years of the twentieth century ${ }^{78}$ There is little evidence also to suggest that the middle classes have withdrawn from the practice of domestic violence. This does not mean that the development of cultures of refinement among the middle classes and elite are not important or influential in the history of interpersonal violence. Those cultures played a part in serving to inhibit and control public acts of violence among the middle classes of Europe, particularly from the eighteenth century onwards. These developments point to real shifts in attitudes to and practices of violence. They also, however, reflected and were products of a consistent desire to ensure that interpersonal violence did not become a dominant force in European life - a desire which was expressed over time in a variety of often very diverse ways.

\section{MAKING SENSE OF INTERPERSONAL VIOLENCE IN EUROPE}

Patterns of interpersonal violence over time and space do not fit neatly within the framework of an over-arching theory such as that offered by the civilising process thesis. The extent of lethal interpersonal violence in the medieval and early modern periods does not support a neat narrative of decline but rather one of fluctuation and variation across time and space. Any fundamental claim to a less violent present, however pretty it is to think so, is undermined by a consideration of the impact

\footnotetext{
Weinstein (1994).

75 Muchembled (2012).

76 Ludwig, Krug-Richter, Schwerhoff (2012).

77 See Carroll (2007, pp. 31-32); see also Frevert (1995).

78 Cottier, Raciti (2013).
} 
of medical interventions on homicide rates, the difficulty of establishing any clear relationship between lethal and non-lethal violence and the difficulties inherent in the use of the available source material.

There have, of course, been changes, variations and shifts in practice. This can be seen in the withdrawal of elites from some shared forms of violent activity and eventually from the practice of duelling and the emergence of a middle class hostility towards particular forms of interpersonal violence. The means used to control violence also evolved over time, reflecting innovations in the courts and legal practice as well as new codes of behaviour - particularly from the eighteenth century onwards. These developments were significant in shaping the history of interpersonal violence but they should not be mistaken for a wider civilising process or be seen as a product of greater levels of 'affect control', nor should they blind us to the underlying continuities which have shaped, and continue to shape, human behaviour over the span of centuries. Such continuities include the predominance of men as perpetrators of lethal violence, the persistence of violence as one means (among others) of defending, asserting or advancing personal status and the attempts, present in all social groups and consistent throughout this period, to ensure that violence was limited and controlled.

The task facing historians of violence is now to map the shifts in interpersonal violence over time and trace how it moved closer to and, at times, further away from the centre of European life over the centuries without imposing overly neat distinctions between historical periods. There also needs to be a transnational focus to future research. Violence cannot be fully understood within the confines of national or regional history, rather we need to explore how the flow and movement of people and ideas across time and space shaped and re-shaped the extent, nature and character of violent activity. We also need to look beyond the boundaries of Europe to draw on the experiences and attitudes that prevail beyond its borders. Historians of violence would also benefit by engaging further with insights from outside the discipline, particularly those offered by psychology and the biological sciences. In doing so, historians should recognise the cross-cultural significance of key forms of social interaction and practice without forcing the complexity of human behaviour into a framework which claims access to knowledge beyond the shaping hand of culture ${ }^{79}$ By adopting a variety of perspectives and embracing new approaches, we can begin to make sense of violence.

Richard Mc Mahon

H.F. Guggenheim Fellow University of Edinburgh rjlmcmahon@gmail.com Richard.McMahon@ed.ac.uk

Joachim Eibach University of Berne joachim.eibach@hist.unibe.ch

Randolph Roth Ohio State University roth.5@osu.edu

$\overline{79}$ For a useful approach, see Shryock, Smail (2011). 


\section{REFERENCES}

Beck, R., Frauen in Krise. Eheleben und Ehescheidung in der ländlichen Gesellschaft Bayerns während des Ancien régime, in van Dülmen, R. (ed.), Dynamik der Tradition, Frankfurt, Fischer, 1992, pp. 137-212.

Brookman, F., Understanding homicide, London, Sage Publications, 2005.

Burghartz, S., Leib, Ehre und Gut. Delinquenz in Zürich Ende des 14. Jahrhunderts, Zürich, Chronos, 1990.

Cockburn, J.S., Patterns of violence in English society: homicide in Kent, 1560-1985, Past and Present, 1991, 130, pp. 70-106.

Carroll, S., Introduction, in Carroll, S. (ed.), Cultures of violence: interpersonal violence in historical perspective, Basingstoke, Palgrave Macmillan, 2007, pp. 128-130.

Cottier, M., Raciti, S., From Honour to Subjectivity: Interpersonal violence in Basel 17501868 and Berne 1861-1944, Crime, Histoire \& Sociétés/Crime, History \& Societies, 2013, 17, 2, [special issue Making sense of violence: essays on interpersonal violence in early modern and modern Europe].

Cronin, J.J., Honour, Duelling and Royal Power in Exile: a case-study of the banished Caroline Stuart Court, c.1649-c.1660, Crime, Histoire \& Sociétés/Crime, History \& Societies, 2013, 17, 2, [special issue Making sense of violence: essays on interpersonal violence in early modern and modern Europe].

Dean, T., Crime and Justice in late medieval Italy, Cambridge, CUP, 2007.

Dinges, M., 'Weiblichkeit' in 'Männlichkeitsritualen'? Zu weiblichen Taktiken im Ehrenhandel in Paris im 18. Jahrhundert, Francia, 1991, 18, pp. 71-98.

Dinges, M., Der Maurermeister und der Finanzrichter. Ehre, Geld und soziale Kontrolle im Paris des 18. Jahrhunderts, Göttingen, V\&R, 1994.

Dinges, M., The Uses of Justice as a Form of Social Control in Early Modern Europe, in Roodenburg, H., Spierenburg, P. (Eds), Social control in Europe, 1500-1800, Columbus, Ohio, Ohio State University Press, 2004, pp. 159-175.

Dooley, E., Homicide in Ireland 1992-1996, Dublin, Stationery Office, 2001.

Eckberg, D.L., Historical Homicide versus Historical Violence: Estimates of Survivable Homicide Deaths in Charleston, South Carolina, 1878-1912, Paper presented at the annual meeting of the Social Science History Association, Chicago, 19 November 2010.

Eibach, J., Frankfurter Verhöre. Städtische Lebenswelten und Kriminalität im 18. Jahrhundert, Paderborn, Schöningh, 2003.

Eibach, J., Der Kampf um die Hosen und die Justiz - Ehekonflikte in Frankfurt im 18.Jahrhundert, in Kesper-Biermann, S., Klippel, D. (Eds), Kriminalität in Mittelalter und Früher Neuzeit, Wiesbaden, Harrassowitz, 2007, pp. 167-188.

Eibach, J., The containment of violence in central European cities, 1500-1800, in Mc Mahon, R. (ed.), Crime, law and popular culture in Europe 1500-1900, Cullompton, Willan, 2008, pp. 52-73.

Eibach, J., Gibt es eine Geschichte der Gewalt? Zur Praxis des Konflikts heute, in der Vormoderne und im 19. Jahrhundert, in Habermas, R., Schwerhoff, G. (Eds), Verbrechen im Blick, Frankfurt, Campus, 2009, pp. 182-216.

Eisner, M., Modernization, self-control and lethal violence: the long-term dynamics of European homicide rates in theoretical perspective, British Journal of Criminology, 2001, 41, 4, pp.18-638.

Eisner, M., Long term trends in violent crime, in Tonry, M. (ed.), Crime and justice : a review of research, (vol. 30) Chicago, University of Chicago Press, 2003, pp. 83-142.

Elias, N. (1939) The civilizing process: sociogenetic and psychogenetic investigations (revised ed.), Oxford, Blackwell, 2000. 
Eriksson, M., Krug-Richter, B. (Eds), Streitkulturen. Gewalt, Konflikt und Kommunikation in der ländlichen Gesellschaft (16.-19. Jahrhundert), Köln, Böhlau, 2003.

Frevert, U., Men of Honour. A social and cultural History of the Duel, Cambridge, Polity, 1995.

Gurr, T.R., Historical trends in violent crime: a critical review of the evidence, in Tonry, M., Morris, N. (Eds), Crime and justice: an annual review of research, Chicago, University of Chicago Press, 1982, 3, pp. 295-353.

Hanawalt, B.A., Growing up in medieval London: the experience of childhood, New York, Oxford University Press, 1993.

Hanlon, G., The decline of violence in the west : from cultural to post-cultural history, English Historical Review, 2013, 128, pp. 367-400.

Hardwick, J., Early modern perspectives on the long history of domestic violence: the case of seventeenth - and eighteenth-century France, The Journal of Modern History, 2006, 78, 1, pp. 1-36.

Ireland, R.W., "Perhaps My Mother Murdered Me": Child death and the law in Victorian Carmarthenshire, in Brooks, C.W., Lobban, M. (Eds), Communities and courts in Britain 1150-1900, London, Hambledon, 1997, pp. 229-244.

Kelly, J., That damn'd thing called honour: duelling in Ireland 1570-1800, Cork, Cork University Press, 1995.

Kiernan, V.G., The Duel in European history: honour and the reign of aristocracy, Oxford, Oxford University Press, 1988.

Kilday, A.-M., Women and Violent Crime in Enlightment Scotland, Woodbridge, Boydell Press, 2007.

King, P., The impact of urbanization on murder rates and on the geography of homicide in England and Wales, 1780-1850, Historical Journal, 2010, 53, 3, pp. 671-698.

Krug-Richter, B., Von Messern, Mänteln und Männlichkeit. Aspekte studentischer Konfliktkultur in Freiburg im Breisgau in der Frühen Neuzeit, Wiener Zeitschrift zur Geschichte der Neuzeit, 2004, 4, pp. 26-52.

Lindström, D., Homicide in Scandinavia: Long-term trends and their interpretations, in BodyGendrot, S., Spierenburg, P. (Eds), Violence in Europe: historical and contemporary perspectives, New York, Springer Science, 2008, pp. 43-64.

Lorenz, M., Das Rad der Gewalt. Militär und Zivilbevölkerung in Norddeutschland nach dem Dreißigjährigen Krieg (1650-1700), Köln, Böhlau, 2007.

Ludwig, U., Von Scherzen und Duellen. Wettkampfspiele als Typus von Ehrkonflikten im schwedisch-pommerschen Offizierskorps, Zeitschrift für historische Forschung, 2011, 38, pp. 371-403.

Ludwig, U., Krug-Richter, B., Schwerhoff, G. (Eds), Das Duell. Ehrenkämpfe vom Mittelalter bis zur Moderne, Konstanz, UVK, 2012.

Muchembled, R., A History of Violence, Cambridge, Polity, 2012.

O'Donnell, I., Lethal violence in Ireland, 1841-2003: Famine, celibacy and parental pacification, British Journal of Criminology, 2005, 45, pp. 671-695.

Mc Mahon, R., Introduction, in Mc Mahon, R. (ed.), Crime, law and popular culture in Europe 1500-1900, Cullompton, Willan, 2008, pp. 9-20.

Mc Mahon, R., Homicide in pre-Famine and Famine Ireland, Liverpool, Liverpool University Press, 2013.

Pinker, S., The better angels of our nature: the decline of violence in history and its causes, London, Allen Lane, 2011.

Povey, D. (ed.), Crime in England and Wales 2002/2003 : Supplementary volume 1 : Homicide and gun crime, London, Home Office, 2004. 
Roth, R., Homicide in early modern England 1549-1800 : the need for a quantitative synthesis, Crime, Histoire \& Sociétés/Crime, History \& Societies, 2001, 5, 2, pp. 33-67.

Roth, R., American Homicide, Cambridge, MA, Harvard University Press, 2009.

Roth, R., Yes we can: working together toward a history of homicide that is empirically, mathematically, and theoretically sound, Crime, Histoire \& Sociétés/Crime, History \& Societies, 2011, 15, 2, pp. 131-145.

Ruff, J.R., Popular violence and its prosecution in seventeenth- and eighteenth-century France, in Mc Mahon, R. (ed.), Crime, law and popular culture in Europe 1500-1900, Cullompton, Willan, 2008, pp. 32-51.

Schmidt, H.R., Hausväter vor Gericht. Der Patriarchalismus als zweischneidiges Schwert, in Dinges, M. (ed.), Hausväter, Priester, Kastraten. Zur Konstruktion van Männlichkeit in Spätmittelalter und Früher Neuzeit, Göttingen, V\&R, 1998, pp. 213-236.

Schuster, P., Eine Stadt vor Gericht. Recht und Alltag im spätmittelalterlichen Konstanz, Paderborn, Schöningh, 2000a.

Schuster, P., Richter ihrer selbst? Delinquenz gesellschaftlicher Oberschichten in der spätmittelalterlichen Stadt, in Blauert, A., Schwerhoff, G. (Eds), Kriminalitätsgeschichte. Beiträge zur Sozial - und Kulturgeschichte der Vormoderne, Konstanz, UVK, 2000b, pp. 359-378.

Schwerhoff, G., Zivilisationsprozess und Geschichtswissenschaft. Norbert Elias' Forschungsparadigma in historischer Sicht, Historische Zeitschrift, 1998, 266, pp. 561605.

Schwerhoff, G., Criminalized violence and the process of civilisation - a reappraisal, Crime, Histoire \& Sociétés/Crime, History \& Societies, 2002, 6, pp. 103-136.

Schwerhoff, G., Social control of violence, violence as social control: the case of early modern Germany, in Roodenburg, H., Spierenburg, P. (Eds), Social control in Europe, 1500-1800, Columbus, Ohio State University Press, 2004, pp. 220-246.

Schwerhoff, G., Historische Kriminalitätsforschung, Frankfurt, Campus, 2011.

Schwerhoff, G., Early Modern Violence and the Honour Code: From Social Integration to Social Distinction ?, Crime, Histoire \& Sociétés/Crime, History \& Societies, 2013, 17, 2, special issue [Making sense of violence : essays on interpersonal violence in early modern and modern Europe].

Sharpe, J.A., The history of violence in England: some observations, Past \& Present, 1985, 108, pp. 206-215.

Sharpe, J.A., Towards a legal anthropology of the early modern Isle of Man, in Mc Mahon, R. (ed.), Crime, law and popular culture in Europe 1500-1900 Cullompton, Willan, 2008, pp. 118-137.

Shoemaker, R., Male honour and the decline of public violence in eighteenth-century London, Social History, 2001, 26 pp. 190-208.

Shoemaker, R., The Taming of the Duel : Masculinity, Honour and ritual Violence in London, 1660-1800, The Historical Journal, 2002, 45, 3, pp. 525-545.

Skoda, H., Medieval violence: physical brutality in Northern France, 1270-1330, Oxford, Oxford University Press, 2013.

Shryock, A., Smail, D.L., Deep history: the architecture of past and present, Berkeley, University of California Press, 2011.

Spierenburg, P., Faces of violence : homicide trends and cultural meanings, Amsterdam, 14311816, Journal of Social History, 1994, 27, pp. 701-716.

Spierenburg, P., Long-term trends in homicide: theoretical reflections and Dutch evidence, fifteenth to twentieth centuries, in Johnson, E.A., Monkkonen, E.H. (Eds), The civilization of crime: violence in town and country since the middle ages, Urbana, University of Illinois Press, 1996, pp. 63-105. 
Spierenburg, P., Violence and the civilizing process: does it work?, Crime, Histoire \& Sociétés/Crime, History \& Societies, 2001, 5, 2, pp. 87-105.

Spierenburg, P., Theorizing in Jurassic Park: a reply to Gerd Schwerhoff, Crime, Histoire \& Sociétés/Crime, History \& Societies, 2002, 6, 2, pp. 127-128.

Spierenburg, P., A history of murder: personal violence in Europe from the middle ages to the present, Cambridge, Polity Press, 2008.

Spierenburg, P., Review of Mc Mahon, R. (ed.), Crime, law and popular culture in Europe 1500-1900, Crime, Histoire \& Sociétés/Crime, History \& Societies, 2010, 14, 1, pp. 103104.

Spierenburg, P., American homicide. What does the evidence mean for theories of violence and society?, Crime, Histoire \& Sociétés/Crime, History \& Societies, 2011a, 15, 2, pp. 123-126.

Spierenburg, P., Questions that remain: Pieter Spierenburg's reply to Randolph Roth, Crime, Histoire \& Sociétés/Crime, History \& Societies, 2011b, 15, 2, pp. 147-150.

Stone, L., Interpersonal violence in English society, 1300-1900, Past \& Present, 1983, 101, pp. 22-33.

Stone, L., A rejoinder, Past \& Present, 1985, 108, pp. 216-224.

van der Heijden, M., Women, Violence and Urban Justice in Holland c. 1600-1838, Crime, Histoire \& Sociétés/Crime, History \& Societies, 2013, 17, 2, special issue [Making sense of violence: essays on interpersonal violence in early modern and modern Europe].

Walz, R., Agonale Kommunikation im Dorf der Frühen Neuzeit, Westfälische Forschungen, 1992, 42, pp. 215-251.

Warner, J., Riviere, J., Graham, K., Men and Women Fighting Side By Side : Examples From an English Town, 1653-1781, Journal of Family History, 2008, 33, 3, pp. 156-172.

Weinstein, D., Fighting or Flyting? Verbal duelling in mid-sixteenth-century Italy, in Dean, T., Lowe, K.J.P. (Eds), Crime, society and the law in Renaissance Italy, Cambridge, Cambridge University Press, 1994.

Wettmann-Jungblut, P., Gewalt und Gegen-Gewalt. Gewalthandeln, Alkoholkonsum und die Dynamik von Konflikten anhand eines Fallbeispiels aus dem frühneuzeitlichen Schwarzwald, in Eriksson, M., Krug-Richter, B. (Eds), Streitkulturen. Gewalt, Konflikt und Kommunikation in der ländlichen Gesellschaft (16.-19. Jahrhundert), Köln, Böhlau, 2003, pp. 17-58.

Wood, J.C., The limits of culture?: Society, evolutionary psychology and the history of violence, Cultural and Social History, 2007, 4, 1, pp. 95-114.

Wood, J.C., A change of perspective: integrating evolutionary psychology into the historiography of violence, British Journal of Criminology, 2011, 51, 3, pp. 479-498. 